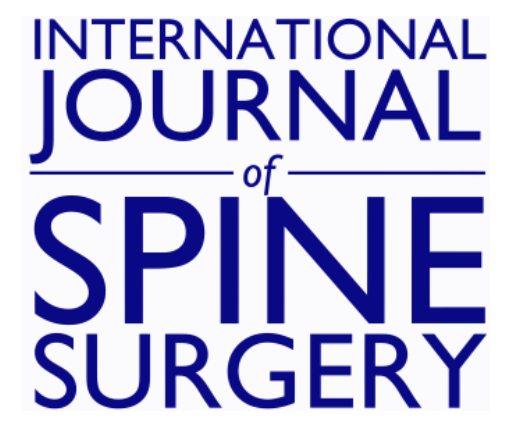

\title{
Vertebroplasty and kyphoplasty for cervical spine metastases: a systematic review and meta-analysis
}

Rafael De la Garza-Ramos, Mario Benvenutti-Regato and Enrique Caro-Osorio

Int J Spine Surg 2016, 10 ()

doi: https://doi.org/10.14444/3007

http://ijssurgery.com/content/10/7

This information is current as of April 26, 2023.

Email Alerts Receive free email-alerts when new articles cite this article. Sign up at:

http://ijssurgery.com/alerts

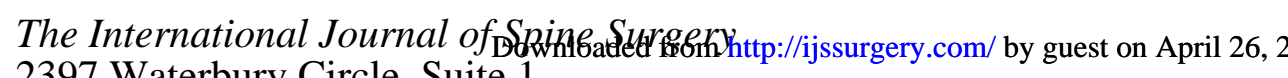
2397 Waterbury Circle, Suite 1,

Aurora, IL 60504, Phone: +1-630-375-1432

(C) 2016 ISASS. All Rights Reserved. 


\section{Vertebroplasty and kyphoplasty for cervical spine metastases: a systematic review and meta-analysis}

Rafael De la Garza-Ramos, MD,1,2 Mario Benvenutti-Regato, MD,1,2,3 Enrique Caro-Osorio, MD 1,2

${ }^{1}$ Tecnológico de Monterrey, School of Medicine and Health Sciences, Monterrey, México, 2Institute of Neurology and Neurosurgery, Hospital Zambrano Hellion Tecnológico de Monterrey, Monterrey, México ${ }^{3}$ Department of Neurosurgery, Universidad Autónoma de Nuevo León, Monterrey, México

\section{Abstract}

\section{Background}

Vertebroplasty (VP) and kyphoplasty (KP) are two minimally invasive techniques used to relieve pain and restore stability in metastatic spinal disease. However, most of these procedures are performed in the thoracolumbar spine, and there is limited data on outcomes after VP/KP for cervical metastases. The purpose of this article is to evaluate the safety and efficacy of VP and KP for treating pain in patients with cervical spine metastases.

\section{Methods}

A systematic review of the literature was conducted using the PubMed and Medline databases. Only studies that reported five or more patients treated with VP/KP in the cervical spine were included. Levels of evidence and grades of recommendation were established based on the Oxford Centre for Evidence-Based Medicine guidelines. Data was pooled to perform a meta-analysis for pain relief and complication rates.

Results

Six studies (all level 4 studies) met the inclusion criteria, representing 120 patients undergoing VP/KP at 135 vertebrae; the most common addressed level was $\mathrm{C} 2$ in 83 cases. The average volume of injected cement was $2.5 \pm 0.5$ milliliters at each vertebra. There were 22 asymptomatic cement leaks (16\%; 95\% CI, 9.8\% - 22.2\%) most commonly occurring in the paraspinal soft tissue. There were 5 complications (4\%; 95\% CI, $0.5 \%-7.5 \%)$ : 3 cases of mild odynophagia, 1 case of occipital neuralgia secondary to leak, and 1 case of stroke secondary to cement embolism. Pain relief was achieved in $89 \%$ of cases (range: $80-100 \%$ ). The calculated average pain score decreased significantly from $7.6 \pm 0.9$ before surgery to $1.9 \pm 0.8$ at last evaluation $(\mathrm{p}=0.006)$.

\section{Conclusion}

Although the calculated complication rate after VP/KP in the cervical spine is low (4\%) and the reported pain relief rate is approximately $89 \%$, there is lack of high-quality evidence supporting this. Future randomized controlled trials are needed.

KEYWORDS: CERVICAL METASTASES, VERTEBROPLASTY, KYPHOPLASTY, SYSTEMATIC REVIEW, SPINAL METASTASES

\section{Introduction}

Spinal metastatic disease is estimated to occur in over two-thirds of patients who die from cancer. ${ }^{1} \mathrm{Al}-$ though the cervical spine is only affected in $8 \%-15 \%$ of cases of spinal metastases, ${ }^{2,3}$ pathologic vertebral compression fractures (VCFs) in this region can be associated with a significant amount of mechanical pain (due to vertebral body destruction), tumorrelated pain (due to mass effect on surrounding painsensitive structures) and/or neurological compromise from spinal cord compression.
Goals of treatment of metastatic spinal disease are mainly palliation and preservation of neurological function. Though patients may be treated with opioids and radiation therapy, up to $30 \%$ of patients may be unresponsive to these modalities, having significant impairment of function, decreased mobility, and others. ${ }^{4,5}$ Vertebroplasty (VP) and kyphoplasty (KP) are two minimally-invasive techniques that aim to provide pain relief and bone stabilization by the injection of cement (usually polymethylmethacrylate; PMMA) into the vertebral body. ${ }^{6}$

While these techniques have shown pain relief in 48 
- $94 \%$ of patients with pathologic VCFs, most of these procedures are performed in the thoracolumbar spine. ${ }^{7}$ This can be attributed to the fact that spinal metastases are more common in this region, but also to the unique anatomy of the cervical spine. Cervical VP and KP is more challenging for several reasons, including a more difficult access for needles ${ }^{8}$ and potential injury to the spinal cord, nerves (including the spinal accessory lingual, vagus, marginal, hypoglossal, and laryngeal), jugular vein, carotid artery, and vertebral artery. ${ }^{9,10}$

The purpose of this article is to give an evidencebased review on the efficacy and safety of VP and KP for pain relief in patients with metastatic disease in the cervical spine.

\section{Methods}

The work in this manuscript followed the PRISMA (Preferred Reporting Items for Systematic Reviews and Meta-Analyses) guidelines. The clinical question was established based on the PICO (patient problem, intervention, comparison, and outcome) method as follows: in adult patients with cervical spine metastases, what are the global outcomes (pain relief, complication rates) following VP and/or KP?

\section{Search algorithm and Study selection}

A search of the PubMed and Medline databases (up to May 19,2015$)$ was performed to identify articles of interest. The algorithm [("vertebroplasty" OR "kyphoplasy") AND "cervical"] was utilized. Articles not involving human subjects or written in a language other than English were excluded (Figure 1). All article titles and abstracts were then screened based on the initial clinical questions, with inclusion criteria as follows: case series with at least 5 patients describing $\mathrm{VP} / \mathrm{KP}$ of the cervical spine ( $\mathrm{C} 1-\mathrm{C} 7)$ for spinal metastasis. Studies were excluded if they reported less than 5 patients, were review articles, involved combined techniques (such as vertebroplasty plus fusion), did not involve metastatic disease, or were large case series with insufficient data to subcategorize outcomes for patients with cervical spine lesions.

Data collected from each study included number of patients, patient age, levels treated, number of vertebra treated, approach, operative technique, primary tumor histology, injected cement volume, pain relief, pain scores (visual analog scale), complications, and follow-up time.

\section{Data Analysis}

Levels of evidence for studies were assigned based on the Oxford Centre for Evidence-based Medicine (CEBM) Levels of Evidence guidelines, which consist of levels 1 - 5 (1: high-quality randomized trial, 2: lesser quality randomized control trial or prospective comparative study, 3: case control study, 4: case series, and 5: expert opinion; http://www.cebm.net/ oxford-centre-evidence-based-medicine-levelsevidenc...).

Grades of recommendations were also assigned according to the Oxford CEBM. These grades consist of Grade A evidence (level 1 studies with consistent findings), Grade B evidence (level 2 or 3 studies with consistent findings), Grade C evidence (level 4 studies with consistent findings), or Grade D evidence (level 5 studies, or inconclusive findings) in favor or against any given intervention.

A descriptive analysis was performed using Microsoft ${ }^{\circledR}$ Excel 2011 for Mac (Redmond, Washington, United States). Data were pooled and analyzed using STATA SE 12 (Stata Corp, College Station, Texas).

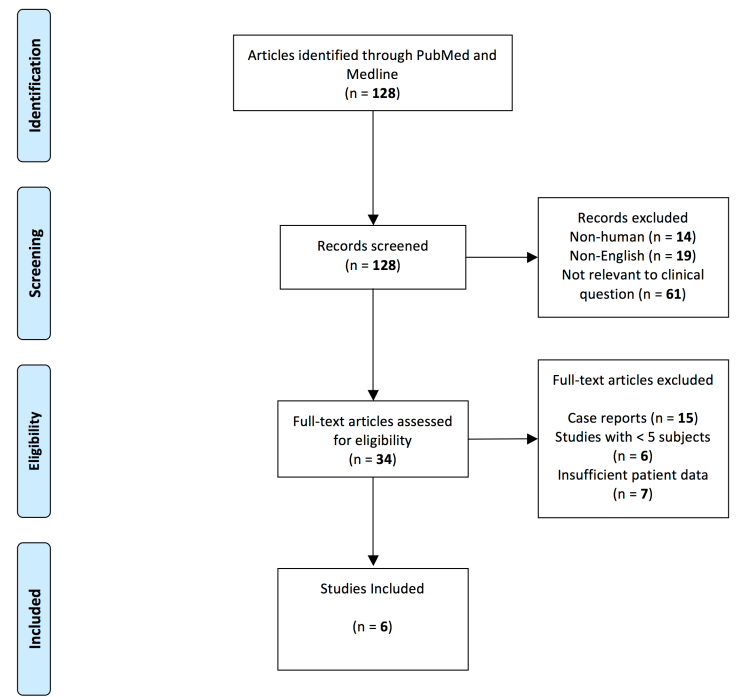

Fig. 1. PRISMA flowchart showing the inclusion/exclusion algorithm. For more information, visit www.prisma-statement.org. 
Variables are presented as means \pm standard deviation or range, and proportions are presented with 95\% confidence intervals (CI) as appropriate. Significance was set at $\alpha=0.05$.

\section{Results}

A total of 6 published case series with at least 5 patients reporting outcomes of patients undergoing $\mathrm{VP} / \mathrm{KP}$ for metastatic cervical spine lesions were identified (Table 1). ${ }^{9-14}$ Based on the Oxford CEBM level of evidence rating, they all correspond to level 4 studies; there has not been any high-quality randomized controlled trial to date specifically addressing the cervical spine.

Five studies examined outcomes after $\mathrm{VP}^{9-13}$ and one after KP. ${ }^{14}$ The studies examined outcomes of 120 patients undergoing treatment at 135 vertebrae. The mean age of all patients was estimated at $59.9 \pm 4.0$ years. The most commonly addressed level was C2 in $61.5 \%(n=83)$ of cases (Figure 2). Half of patients $(n=60)$ were approached transorally and 60 were approached either via an anterolateral or posterolateral percutaneous approach (Figure 3). Tumor histology is depicted in Figure 4, and the most common was breast cancer in 34 cases. The average volume of injected cement was $2.5 \pm 0.5$ milliliters at each vertebra. Biplanar fluoroscopy (C-arm) was used in all studies, but two also reported CT-guided VP/KP in some patients. ${ }^{12,13}$

There were a total of 22 asymptomatic cement leaks (16.0\% of all treated vertebrae; $95 \%$ CI, 9.8\% - 22.2\%). Leaks from the 22 vertebrae were found more fre- quently in the paraspinal soft tissues along the needle tract $(\mathrm{n}=18)$, followed by the epidural venous plexus $(\mathrm{n}=7)$, paraspinal veins $(\mathrm{n}=4)$, intervertebral foramina $(n=3)$, disc below $(n=1)$ and posteriorly $(n=1)$. There were 5 ( $4 \%$ of all patients; $95 \%$ CI, $0.5 \%-7.5 \%$ ) perioperative complications. These complications ranged from mild (three cases of mild odynophagia and one case of occipital neuralgia due to leakage) to severe (one case of acute cerebellar and occipital infarction due to cement leakage).

Success was defined as complete pain resolution or a significant improvement in pain, and was achieved in $89 \%$ of cases (range: $80-100 \%$ ). The calculated average pain score decreased significantly from $7.6 \pm 0.9$ before surgery to $1.9 \pm 0.8$ at last evaluation $(\mathrm{p}=0.006)$. Patients were followed for an average of $10.7 \pm 6.3$ (range: $3-21.8$ ) months.

\section{Grades of Recommendation}

Given the absence of high-quality evidence, there is

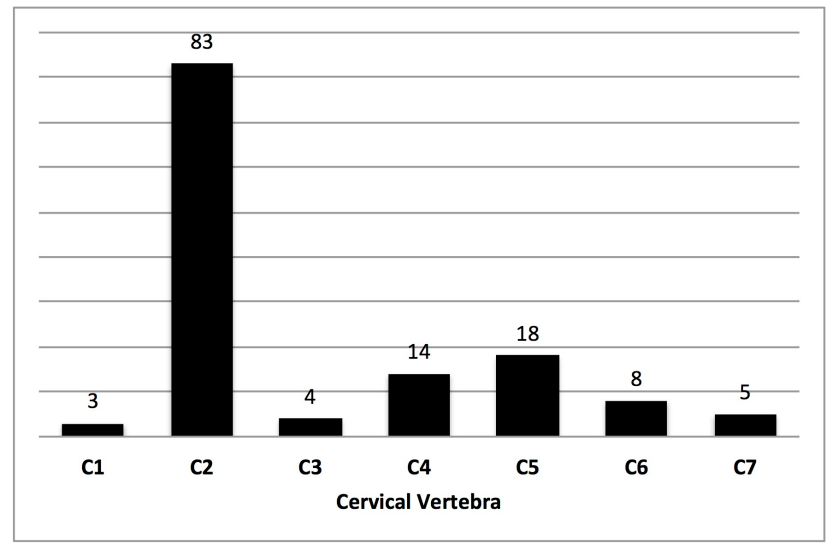

Fig. 2. Distribution of treated cervical vertebrae.

Table 1. Summary of published case series reporting outcomes after vertebroplasty or kyphoplasty for metastatic cervical spine lesions

\begin{tabular}{|c|c|c|c|c|c|c|c|c|c|c|c|}
\hline Study & $\begin{array}{r}\text { No. Of } \\
\text { patients }\end{array}$ & $\begin{array}{r}\text { No. Vertebral } \\
\text { bodies }\end{array}$ & $\begin{array}{r}\text { Treated } \\
\text { levels }\end{array}$ & Age & $\begin{array}{r}\text { Injected } \\
\text { volume }\end{array}$ & Success & $\begin{array}{l}\text { Preop } \\
\text { VAS }\end{array}$ & $\begin{array}{r}\text { Postop } \\
\text { VAS }\end{array}$ & $\begin{array}{r}\text { Asymptomatic } \\
\text { leakage }\end{array}$ & Complications & FU \\
\hline $\begin{array}{l}\text { Mont'Alverne et } \\
\text { al., } 2005\end{array}$ & 12 & 12 & $\mathrm{C} 2$ & 52.3 & 2.7 & $80 \%$ & - & - & 6 & $\begin{array}{r}1 \text { occipital } \\
\text { neuralgia, } 1 \text { stroke; }\end{array}$ & 6.9 \\
\hline $\begin{array}{l}\text { Pflugmacher et } \\
\text { al., } 2006\end{array}$ & 5 & 12 & $\mathrm{C} 3-\mathrm{C} 7$ & 60.4 & 1.8 & - & 6.3 & 2.9 & 2 & None & 12 \\
\hline Sun et al., 2010 & 10 & 10 & $\begin{array}{r}\text { C2, } \\
\text { others }\end{array}$ & 62.1 & 3 & $100 \%$ & - & - & 4 & $\begin{array}{r}3 \text { cases of mild } \\
\text { odynophagia }\end{array}$ & 10.7 \\
\hline $\begin{array}{l}\text { Masala et al., } \\
2011\end{array}$ & 62 & 70 & $\mathrm{C} 1-\mathrm{C} 7$ & 61.5 & 2.5 & $97 \%$ & 7.9 & 1.7 & 2 & None & 3 \\
\hline $\begin{array}{l}\text { Anselmetti et al., } \\
2012\end{array}$ & 25 & 25 & $\mathrm{C} 2$ & 59.3 & - & $80 \%$ & 8.1 & 1.0 & 6 & None & 21.8 \\
\hline $\begin{array}{l}\text { Blondel et al., } \\
2012\end{array}$ & 6 & 6 & $\mathrm{C} 2-\mathrm{C} 5$ & 63.5 & - & - & 8.0 & 2.0 & 2 & None & 10 \\
\hline Total & 120 & 135 & & $\begin{array}{r}59.9 \pm \\
4.0\end{array}$ & $2.5 \pm 0.5$ & $89 \%$ & $\begin{array}{r}7.6 \pm \\
0.9\end{array}$ & $\begin{array}{r}1.9 \pm \\
0.8\end{array}$ & $\begin{array}{r}22(16 \% ; 95 \% \mathrm{CI} \\
9.8-22.2)\end{array}$ & $\begin{array}{r}5(4 \% ; 95 \% \text { CI, } 0.5 \\
-7.5 \%)\end{array}$ & $\begin{array}{r}10.7 \pm \\
6.3\end{array}$ \\
\hline
\end{tabular}

Success was defined as being pain-free or experiencing a statistically significant reduction in pain; VAS: visual analog scale; FU: follow-up.

Downloaded from http://ijssurgery.com/ by guest on April 26, 2023 
insufficient data in favor/against VP/KP for cervical metastases. Based on the current analyzed data, there is grade C evidence (low quality) suggesting that $\mathrm{VP} / \mathrm{KP}$ achieves significant reductions in pain scores with a low perioperative complication rate.
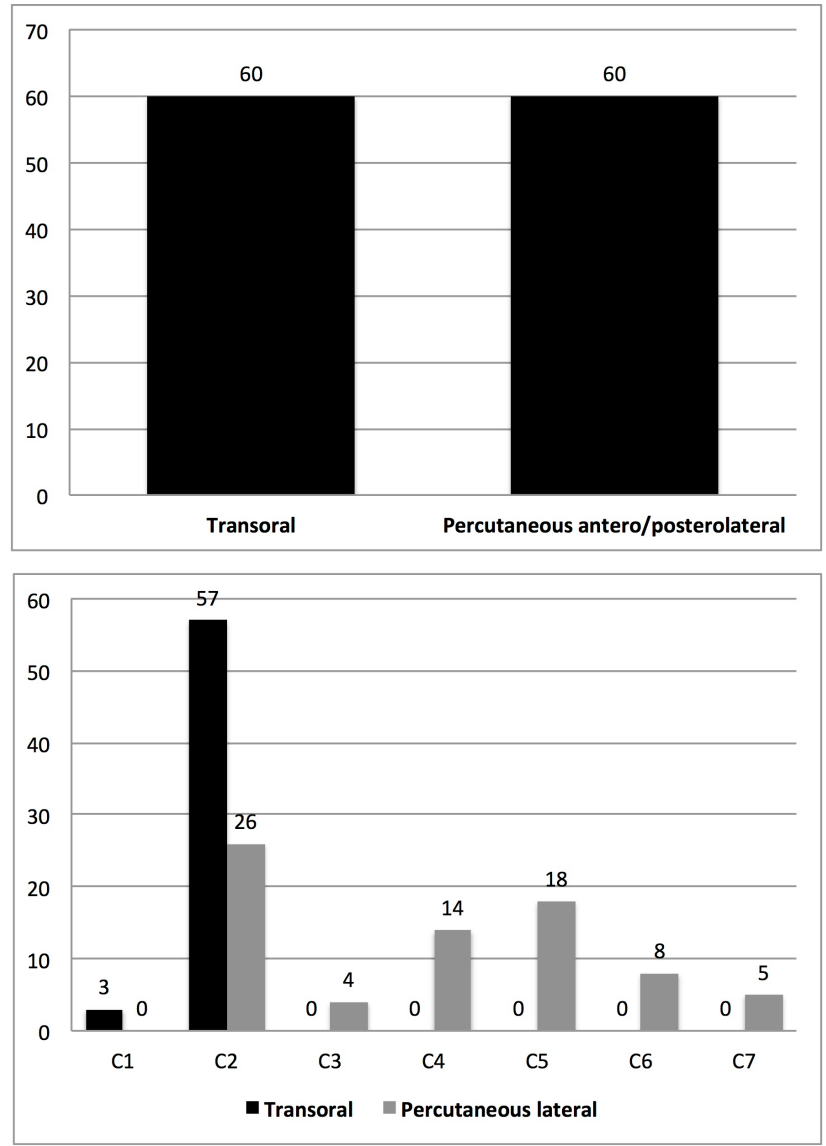

Fig. 3. Approaches to the cervical spine. Top: Overall approaches. Bottom: Approaches by cervical spine level.

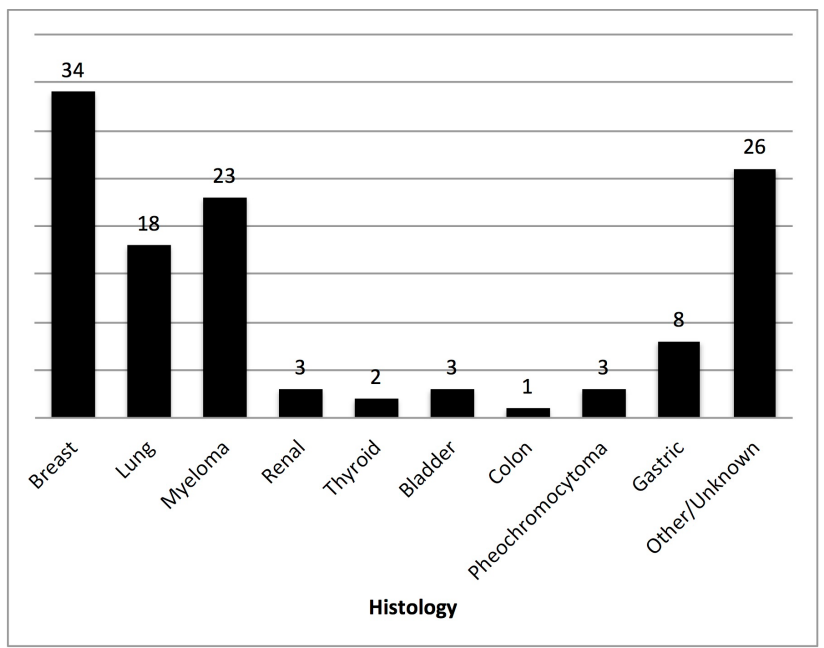

Fig. 4. Primary tumor histologies.
Surgical technique and complication avoidance The approach to the cervical spine for VP/KP is mostly dependent on tumor location and the operating physician, as mentioned previously. Images showing an anterolateral approach for a C2 vertebroplasty are displayed in Figure 5 . Procedures are performed under a C- or O-arm for adequate imaging guidance. Patients are premedicated with intravenous antibiotic therapy, and non-invasive ventilation with a generic mask may be performed. Patients are placed supine with moderate hyperextension of the neck, and sedation administered; ${ }^{9}$ others prefer general anesthesia. ${ }^{13,14}$ After skin preparation, local anesthetic is administered, and an anterolateral access is used to insert a 14-gauge, 10-cm-long beveled needle under continuous lateral fluoroscopy if a percutaneous approach is desired. Entry point is "approximately $1 \mathrm{~cm}$ below the angle of the mandible and anterolateral to the visceral space, advanced carefully in an oblique (posterior, cranial, and medial) direction via the parapharyngeal, retropharyngeal, and prevertebral spaces into the $\mathrm{C} 2$ vertebral body." 12 During percutaneous approaches, the carotid artery should be localized by palpation, and displaced laterally by the operator's hand. ${ }^{12}$

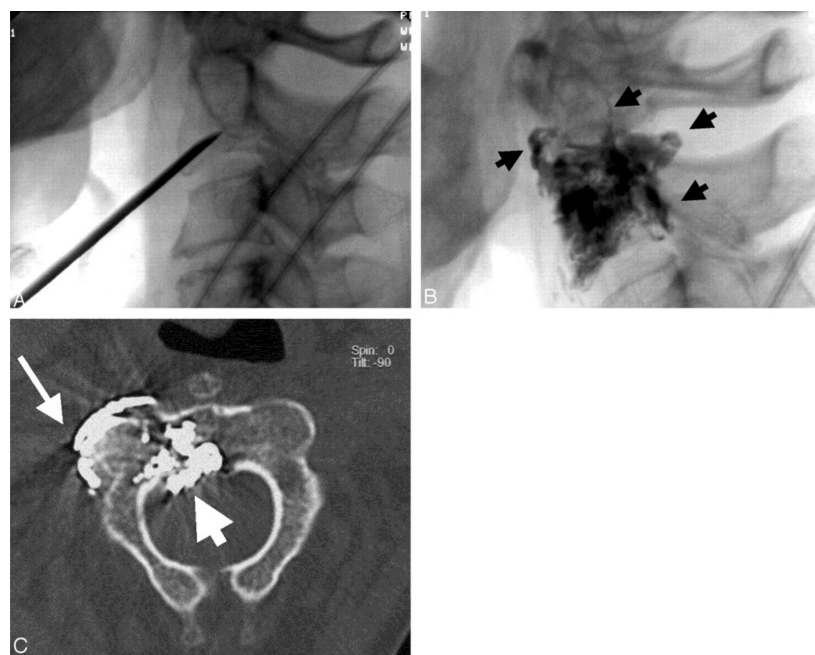

Fig. 5. Breast cancer with multiple spinal involvements. A, Lateral radiograph obtained after placement of the needle shows its oblique trajectory and the approach to $\mathrm{C} 2$. Note that the needle is placed at the central part of the vertebral body. B, Lateral radiograph, obtained after percutaneous vertebroplasty, shows a satisfactory opacification of the vertebral body but also a cement leakage (arrows). C, Axial CT scan, obtained after percutaneous vertebroplasty, shows cement leakage in the epidural space (short arrow), as well as leakage close to the C1-C2 joint (long arrow). The latter caused a transient occipital neuralgia. (Reprinted with permission, Francisco Mont'Alverne et al. AJNR Am J Neuroradiol 2005;26:1641-1645) 
On the other hand, an "open" approach may also be utilized, in which a standard cervical approach is performed, along with soft tissue dissection until the vertebral body is exposed. ${ }^{11,14}$ Once the needle is within the vertebral body, the needle is rotated and advanced into the middle of the vertebral body, under lateral and anteroposterior fluoroscopic guidance. The cement is then injected through the needle using a $20-\mathrm{mL}$ syringe, always under imaging guidance to identify potential leakage. The volume to be injected is dependent on the specific vertebral body, but is usually around $2.5 \mathrm{~mL}$ at $\mathrm{C} 2 .^{9,13}$

\section{Discussion}

Vertebroplasty and kyphoplasty are relatively new techniques used to treat painful VFCs unresponsive to medical management. ${ }^{15}$ First introduced in 1987 by French neuroradiologist Hervé Dearamond, VP involves the direct injection of cement into the vertebral body. On the other hand, KP involves inflating a small balloon to restore angular deformity prior to cement injection; both techniques are usually performed percutaneously. Ideal candidates are patients with mechanical pain secondary to recent VCFs (osteoporotic, tumor-related, etc.) without significant neural compression from bone fragments. ${ }^{15}$

Although the mechanism for pain reduction is not entirely understood, it is believed that the injected cement stabilizes pathological microfractures and reduces mechanical forces that irritate nervous structures. ${ }^{16}$ Biomechanically, it has been shown that filling of $13-16 \%$ of the vertebral body is necessary to restore vertebral strength. ${ }^{17}$ In spite of their widespread use to treat VCFs due to metastatic disease, there is lack of high-quality evidence in favor of VP/ $\mathrm{KP}$ compared to medical or surgical treatment. ${ }^{7}$ In a systematic review by McGirt et al., data was pooled from 18 studies reporting outcomes of 698 patients who received VP or KP for VCFs secondary to tumors. There were no Level 1, 2, or 3 studies, and cumulative analysis suggested a significant reduction in pain with a low morbidity. However, most of these studies involved fractures in the thoracolumbar region, given the challenging nature of performing such procedures in the cervical spine (access and potential injury to spinal cord and/or vertebral arter- ies) ${ }^{6}$

In the present study, we sought to investigate outcomes after VP/KP for metastatic tumors in the cervical spine. We performed a thorough literature review, and similar to McGirt et al.'s findings in 2009, we found no high-quality studies suggesting VP/KP provides better outcomes than medical or surgical treatment for VCFs secondary to metastatic lesions (including the cervical spine). Six studies were included in our analysis, all of them graded as Level 4 evidence. ${ }^{9-14} \mathrm{~A}$ total of 120 patients were included in our review, undergoing treatment at 135 levels. We found that the most common treated level was C2, which was treated in 83 cases $(61.5 \%)$. Metastases to the craniocervical junction (including the axis) are uncommon, comprising only $0.5 \%$ of all spine metastases. ${ }^{18}$ The reason for the higher prevalence of $\mathrm{C} 2$ metastases in this study is unknown, but is has been hypothesized that given the higher risk of severe spinal cord injury in this region, "the potential complications of instability at this level compared to caudad levels likely influences the decision to operate."19 This specific level was approached percutaneously in several case series, ${ }^{9,11,12,14}$ and transorally in others. ${ }^{10,13}$ While the transoral approach is more direct, it is associated with higher complication rates. ${ }^{20,21}$ On the other hand, the anterolateral approach to C2 may reduce the infection rate, but has a higher neurovascular injury risk. ${ }^{14}$

On average, patients received $2.5 \mathrm{~mL}$ of cement into each vertebra. Volumetric studies have estimated the vertebral body volume of $\mathrm{C} 2$ to be $6.3 \pm 1.1 \mathrm{~cm}^{3}$, ${ }^{22}$ while the volumes of $\mathrm{C} 3-\mathrm{C} 7$ have been estimated to be $10.4 \pm 1.9,10.5 \pm 2.0,11.1 \pm 2.1,12.4 \pm 2.5$, and $15.4 \pm 2.8 \mathrm{~cm}^{3}$, respectively. Thus, vertebral bodies were filled on average $40 \%$ at C2, 24\% at C3, 23.8\% at $\mathrm{C} 4,22.5 \%$ at $\mathrm{C} 5,20.2 \%$ at C6, and $16.2 \%$ at C7. As mentioned previously, biomechanical studies have suggested that filling of at least $16 \%$ of the vertebral body is necessary for restoration of compressive strength and/or to achieve equal stress distribution, ${ }^{17}$ which was almost certainly achieved in all cases.

Our review also found a $16 \%$ risk of asymptomatic cement leaks, which has been shown to occur in up to $75 \%$ of patients in the literature. ${ }^{6}$ Most of these oc- 
curred in the paraspinal soft tissues along the needle tract, followed by the epidural venous plexus. The complication rate was relatively low (4\%), but one of these cases was a cerebellar and occipital stroke due to cement embolism. ${ }^{9}$ However, the authors reporting that case mentioned that "these symptoms regressed partially during follow-up." " Other complications that have been reported in single case reports and smaller case series following VP/KP in the cervical spine include tumor extravasation, ${ }^{23}$ and infection in cases of transoral approaches. ${ }^{21}$ In a retrospective study comparing outcomes of VP versus KP for metastatic lesions in the vertebral column, the authors found that asymptomatic leakage was significantly more likely to occur following VP (30.3\%) when compared to KP (16.9\%). ${ }^{24}$

Strategies to potentially prevent substantial cement leaks include 1) use of high-resolution fluoroscopy or $\mathrm{CT}, 2$ ) adequate cement opacification, and 3) interruption or termination of cement injection upon first recognition of a leak. ${ }^{25}$ Stroke and other neurological complications secondary to extravasation of cement can also be potentially avoided by adequate visualization of vertebral bodies during the procedure and cement opacification. ${ }^{26}$ The latter can be done by addition of sterile tantalum or tungsten, which "greatly enhances its visibility fluoroscopically and ensures that injection of cement is stopped once it approaches the posterior vertebral cortex." 26

Although no high-quality evidence has suggested $\mathrm{VP} / \mathrm{KP}$ is more effective than medical or surgical treatment, our analysis showed that pain relief is achieved on average in $89 \%$ of patients $(80-100 \%)$, with a significant reduction in pain scores. Li et al. reported that both VP and KP achieved equal pain relief for metastatic lesions, but VP was associated with a shorter hospital stay and lower hospital costs. ${ }^{24}$ However, that study was not specific to cervical spine metastases.

Currently, there is low-quality evidence supporting the use of VP/KP to treat painful VCFs secondary to metastatic lesions in the cervical spine. However, the best available evidence suggests that a significant reduction in pain may be achieved, with a relatively low risk of major complications. Future larger-scale stud- ies and randomized controlled trials comparing VP/ $\mathrm{KP}$ versus medical treatment or surgery for cervical metastases are needed to corroborate our findings.

\section{Conclusion}

Following a systematic review and meta-analysis of the current best-available evidence regarding outcomes of $\mathrm{VP} / \mathrm{KP}$ for metastatic cervical spine lesions, it was found that a significant reduction in pain may be achieved ( $80-100 \%$ of patients), with a low risk (4\%) of complications ( $\mathrm{Grade} C \mathrm{Crecommenda-}$ tion). However, there are no high-quality studies to date addressing this question, and more studies are needed to confirm this.

\section{References}

1. Hage WD, Aboulafia AJ, Aboulafia DM. Incidence, location, and diagnostic evaluation of metastatic bone disease. Orthop Clin North Am. Oct 2000;31(4):515-528, vii.

2. Constans JP, de Divitiis E, Donzelli R, Spaziante $\mathrm{R}$, Meder JF, Haye C. Spinal metastases with neurological manifestations. Review of 600 cases. J Neurosurg. Jul 1983;59(1):111-118.

3. Brihaye J, Ectors P, Lemort M, Van Houtte P. The management of spinal epidural metastases. $A d v$ Tech Stand Neurosurg. 1988;16:121-176.

4. Janjan N. Bone metastases: approaches to management. Semin Oncol. Aug 2001;28(4 Suppl

11):28-34.

5. Schachar NS. An update on the nonoperative treatment of patients with metastatic bone disease. Clin Orthop Relat Res. Jan 2001(382):75-81.

6. Pilitsis JG, Rengachary SS. The role of vertebroplasty in metastatic spinal disease. Neurosurg Focus. Dec 15 2001;11(6):e9.

7. McGirt MJ, Parker SL, Wolinsky JP, Witham TF, Bydon A, Gokaslan ZL. Vertebroplasty and kyphoplasty for the treatment of vertebral compression fractures: an evidenced-based review of the literature. Spine J. Jun 2009;9(6):501-508.

8. Huegli RW, Schaeren S, Jacob AL, Martin JB, Wetzel SG. Percutaneous cervical vertebroplasty in a multifunctional image-guided therapy suite: hybrid lateral approach to $\mathrm{C} 1$ and $\mathrm{C} 4$ under $\mathrm{CT}$ and fluoro- 
scopic guidance. Cardiovasc Intervent Radiol. Sep-Oct 2005;28(5):649-652.

9. Mont'Alverne F, Vallee JN, Cormier E, et al. Percutaneous vertebroplasty for metastatic involvement of the axis. AJNR Am J Neuroradiol. Aug

2005;26(7):1641-1645.

10. Anselmetti GC, Manca A, Montemurro F, et al. Vertebroplasty using transoral approach in painful malignant involvement of the second cervical vertebra (C2): a single-institution series of 25 patients.

Pain Physician. Jan-Feb 2012;15(1):35-42.

11. Pflugmacher R, Schleicher P, Schroder RJ, Melcher I, Klostermann CK. Maintained pain reduction in five patients with multiple myeloma 12 months after treatment of the involved cervical vertebrae with vertebroplasty. Acta Radiol. Oct 2006;47(8):823-829.

12. Sun G, Jin P, Li M, et al. Percutaneous vertebroplasty for treatment of osteolytic metastases of the C2 vertebral body using anterolateral and posterolateral approach. Technol Cancer Res Treat. Aug 2010;9(4):417-422.

13. Masala $S$, Anselmetti GC, Muto M, Mammucari M, Volpi T, Simonetti G. Percutaneous vertebroplasty relieves pain in metastatic cervical fractures. Clin Orthop Relat Res. Mar

2011;469(3):715-722.

14. Blondel B, Adetchessi T, Demakakos J, PechGourg G, Dufour H, Fuentes S. Anterolateral kyphoplasty in the management of cervical spinal metastasis. Orthop Traumatol Surg Res. May 2012;98(3):341-345.

15. Burton AW, Rhines LD, Mendel E. Vertebroplasty and kyphoplasty: a comprehensive review. Neurosurg Focus. Mar 15 2005;18(3):e1.

16. Cotten A, Dewatre F, Cortet B, et al. Percutaneous vertebroplasty for osteolytic metastases and myeloma: effects of the percentage of lesion filling and the leakage of methyl methacrylate at clinical follow-up. Radiology. Aug 1996;200(2):525-530.

17. Boszczyk B. Volume matters: a review of procedural details of two randomised controlled vertebroplasty trials of 2009. Eur Spine J. Nov

2010;19(11):1837-1840.

18. Sherk HH. Lesions of the atlas and axis. Clin

Orthop Relat Res. 1975(109):33-41.

19. Baker JF, Shafqat A, Devitt A, McCabe JP. Sta- bilization of metastatic lesions affecting the second cervical vertebra. J Craniovertebr Junction Spine. Apr-Jun 2015;6(2):56-59.

20. Hadley C, Awan OA, Zoarski GH. Biomechanics of vertebral bone augmentation. Neuroimaging Clin N Am. May 2010;20(2):159-167.

21. Jones DC, Hayter JP, Vaughan ED, Findlay GF. Oropharyngeal morbidity following transoral approaches to the upper cervical spine. Int J Oral Maxillofac Surg. Aug 1998;27(4):295-298.

22. Crawford B, Kim DG, Moon ES, et al. Cervical vertebral bone mineral density changes in adolescents during orthodontic treatment. Am J Orthod Dentofacial Orthop. Aug 2014;146(2):183-189.

23. Cruz JP, Sahgal A, Whyne C, Fehlings MG, Smith R. Tumor extravasation following a cement augmentation procedure for vertebral compression fracture in metastatic spinal disease. J Neurosurg Spine. Sep 2014;21(3):372-377.

24. Li Z, Ni C, Chen L, et al. Kyphoplasty versus vertebroplasty for the treatment of malignant vertebral compression fractures caused by metastases: a retrospective study. Chin Med J (Engl).

2014;127(8):1493-1496.

25. Mathis JM. Percutaneous vertebroplasty: complication avoidance and technique optimization. AJNR Am J Neuroradiol. Sep 2003;24(8):1697-1706. 26. Harrington KD. Major neurological complications following percutaneous vertebroplasty with polymethylmethacrylate: a case report. J Bone Joint Surg Am. Jul 2001;83-A(7):1070-1073.

\section{Disclosures}

The authors have no conflict of interests or funding sources to declare.

\section{Corresponding Author}

Enrique Caro-Osorio, M.D., Institute of Neurology and Neurosurgery, Hospital Zambrano Hellion Tecnológico de Monterrey, Batallón de San Patricio \#112, $8^{\text {th }}$ Floor, Monterrey, México66278. ecaro@itesm.mx.

Published 26 January 2016.

This manuscript is generously published free of charge by ISASS, the International Society for the

Downloaded from http://ijssurgery.com/ by guest on April 26, 2023 
Advancement of Spine Surgery. Copyright @ 2016

ISASS. To see more or order reprints or permissions, see http://ijssurgery.com. 